\title{
Serving the Needs of Homeless Library Patrons: Legal Issues, Ethical Concerns, and Practical Approaches
}

Paul Kaidy Barrows

San Jose State University, paul.kaidy.barrows@gmail.com

Follow this and additional works at: https://scholarworks.sjsu.edu/ischoolsrj

Part of the Library and Information Science Commons

\section{Acknowledgements}

This article was originally written to fulfill the requirements of LIBR 200, Information and Society, taught by Dr. Scott Walter, as part of the MLIS program at the San Jose State University School of Information.

\section{Recommended Citation}

Barrows, P. K. (2014). Serving the Needs of Homeless Library Patrons: Legal Issues, Ethical Concerns, and Practical Approaches. School of Information Student Research Journal, 4(2). https://doi.org/10.31979/ 2575-2499.040203 Retrieved from https://scholarworks.sjsu.edu/ischoolsrj/vol4/iss2/3

This article is brought to you by the open access Journals at SJSU ScholarWorks. It has been accepted for inclusion in School of Information Student Research Journal by an authorized administrator of SJSU ScholarWorks. Formore information, please contact scholarworks@sjsu.edu. 


\title{
Serving the Needs of Homeless Library Patrons: Legal Issues, Ethical Concerns, and Practical Approaches
}

\begin{abstract}
While cognizant of their social mission, public libraries often still have found it challenging to serve one of their most marginalized constituencies - the homeless. However, bound by legal mandate as well as American Library Association (ALA) core values of access, democracy, and serving the public, libraries must find ways to serve the needs of poor and homeless patrons. This paper describes the demographics and characteristics of homelessness, explores legal and ethical issues with regard to library services, identifies selected model library programs that serve this population effectively, and provides practical guidance and recommendations to public libraries and librarians struggling with this matter, including how to draft patron codes of behavior that are consistent with legal guidelines. Serving the poor and homeless is both a challenge and an opportunity to put the American Library Association's core values into practice. In so doing, public libraries model the democratic principles they would have their patrons emulate, not only demonstrating but creating the kind of society for which they stand.
\end{abstract}

\section{Keywords}

homelessness, poverty, library service, patron behavior, behavior codes, policy, ethics, legal issues

\section{Acknowledgements}

This article was originally written to fulfill the requirements of LIBR 200, Information and Society, taught by Dr. Scott Walter, as part of the MLIS program at the San Jose State University School of Information.

\section{About Author \\ Paul Kaidy Barrows is a MLIS candidate at San Jose State University. A web and information services professional for more than a dozen years, his passion is empowering seekers and learners through technology and education.}


While cognizant of their social mission, public libraries still have often found it challenging to serve one of their most marginalized constituencies - the homeless. In an essay in American Libraries, Will Manley (1998) wrote, "The homeless can be the bane of our existence; but despite the inconveniences that they create, we librarians are consistently in the forefront of championing their needs and securing their rights" (p. 128). It is telling that Manley wrote those words during an economic boom period. Now, following a chronically stalled economy, the lives of the poor and homeless have become even more tenuous - and as a result they are reaching out to public libraries even more (see, for example, Lai, 2012; MacNaughton, 2011; Scott, 2012).

American Library Association (ALA) core values of access, democracy, and serving the public good make it an ethical imperative to serve the needs of the poor and homeless (American Library Association, 2004; 2008; 2012; 2014); and, according to a landmark lawsuit (Kreimer v. Morristown - see Ballard-Thrower, R A. (1992); Barber (2012)), libraries have a legal mandate to do so as well. But how can public libraries accommodate this often misunderstood, disparaged, and underserved group?

This paper aims to provide background, insights, and guidance to public libraries and librarians struggling with this matter. Information has been drawn largely from peer-reviewed journals, most sources having been published within the last 10 years. Beginning with an overview of pertinent issues together with their legal and ethical dimensions, the exploration moves on to examine selected library programs that serve this population effectively, and to consider a trend among library schools to provide social service-related coursework and training. Finally, the discussion section will distill some key recommendations for library professionals about how to address the needs of their homeless patrons.

Providing services to the poor and homeless may test the commitment of public libraries to democracy and equal access, but ultimately it is an opportunity to put the American Library Association's core values into practice.

\section{Why Serve the Homeless?}

\section{Legal Issues}

Kreimer v. Morristown, NJ is a landmark federal case relating to intellectual freedom, public libraries, and the First Amendment (Barber, 2012). Richard Kreimer was a homeless public library patron whose odor and behavior (staring at patrons and following them around, and responding aggressively to library staff) was disturbing to patrons and library administration. In response to this particular individual, the library established several behavior policies that led to Kreimer's repeated expulsion. Following his fifth expulsion, Kreimer sued Morristown, NJ, 
claiming that his constitutional rights were being violated (Ballard-Thrower, 1992; Barber, 2012; Geiszler, 1998).

Although the District Court, where the suit was originally filed, and the subsequent Appeals Court, varied somewhat in their findings regarding the library's actions, two extremely important legal rulings vis-à-vis public libraries came out of the litigation. The first is that there is a constitutionally protected right to receive information under the First Amendment; i.e., that freedom of expression is not just limited to freedom of speech, but also includes the right to free access to information. Thus, any attempt by a library to limit patrons' access is subject to Constitutional scrutiny, and may be a violation of their civil rights (Ballard-Thrower, 1992; Barber, 2012; Geiszler, 1998; Hitchcock, 2005).

The second important ruling established that it is permissible for libraries to expel patrons who violate behavior policies, as long as those policies meet First Amendment standards. That is, that they are reasonable, and not vague, and not overbroad in their application (Barber, 2012; Geiszler, 1998; Hitchcock, 2005). Later in this paper, the creation of patron behavior policies will be explored in some detail, as adopting such a policy is very much to a public library's advantage (Barber, 2012).

\section{Ethics and Values}

The ethics and values of public librarianship derive from a history of supporting human rights and the public good (McCook and Phenix, 2006). The American Library Association's stance on the responsibility of libraries toward economically vulnerable patrons is unequivocal. Core values of access, democracy, service, and social responsibility create an ethical mandate to serve the poor and homeless (American Library Association, 2004). As stated in the American Library Association's Policy B.8.10, Library Services to the Poor: "It is crucial that libraries recognize their role in enabling poor people to participate fully in a democratic society, by utilizing a wide variety of available resources and strategies" (American Library Association, 2014). The policy aims to reduce economic barriers to library use, as well as to promote greater understanding among librarians and within society of poverty's dimensions. In addition, the American Library Association's Social Responsibilities Round Table formed the Hunger, Homelessness, and Poverty Task Force in 1996 to "foster greater awareness of the dimensions, causes, and ways to end hunger, homelessness, and poverty" (American Library Association, 2012).

Serving the poor and homeless is both a challenge and an opportunity to put the American Library Association's core values into practice (Ayers, 2006). By offering information on a world of topics from the practical to the esoteric, public libraries can connect the poor and homeless to both essential resources and 
possibilities for personal growth (Ayers, 2006; Murphy, 1999). The public library can serve as a unique space where members of different social strata may interact - sometimes with conflict but sometimes with increased mutual familiarity and understanding. The public library can also take an active role in reaching out to social service agencies, even partnering with them to offer comprehensive services (Murphy, 1999).

As a result of living and working within a society that often equates material wealth with social worth, even the best-intentioned librarians may hold ambivalent or classist feelings toward their poor and homeless patrons (Berman, 2007). They may need to engage in careful self-assessment to evaluate how well they are actually adhering to American Library Association ideals. More than being sources for specific types of information, librarians must be aware of their attitude when assisting the poor and homeless, whose interactions with the institutional establishment frequently leave them feeling unworthy (Berman, 2007; Hersberger, 2005; Holt, 2006).

\section{Information Needs of the Homeless}

The homeless have a range of information needs including information about finances, relationships, childcare, housing, health and health care, employment, education, transportation, and public assistance (Hersberger, 2005). In addition, because full participation in society in general - and specifically in the areas of education, employment, and government - now requires access to technology and the Internet, the homeless keenly experience the "digital divide" and rely on public libraries to bridge this gap (Ayers, 2006; Collins, 2009; Hersberger, 2002; Jaeger, Bertot, \& Thompson, 2012). Among homeless children, unfamiliarity with computer use, computer games, and computer technology not only can set them back academically, but can stigmatize them socially among their peers (Norfolk, 1995).

A paramount need among the homeless is for information about food and housing (Holt \& Holt, 2010; Lai, 2012). Reference librarians trained to assist patrons with research questions may be unprepared to answer inquiries about such basic physiological needs. Holt \& Holt (2010) recommend that public libraries compile comprehensive information about community resources - for example, those where the homeless can get a bed and food - and put this information on the library's website. When patrons ask a librarian for referrals to such resources, the librarian can immediately go to the website and print off the appropriate listings. Or, patrons who do not wish to speak directly with a librarian can access the information themselves from a computer kiosk within the library.

Muggleton and Ruthven (2011) caution librarians not to err by placing exclusive attention on providing referrals to basic services. These authors point 
out that homeless patrons also need information that fosters higher social and intellectual growth, reminding librarians that the homeless have the same emotional, self-esteem, and identity needs as others.

\section{Patron Codes of Behavior}

In spite of the efforts of public libraries to serve all patrons fairly, including homeless patrons, the potential exists for real conflict between the homeless and other patrons and staff, leading some librarians to label the homeless as problem patrons. In the midst of such conflict, librarians must carefully differentiate between what is truly problem behavior, and what is really only nuisance behavior (Murphy, 1999). Holt \& Holt (2005), who have written extensively on the subject of serving poor and homeless library patrons, make a statement somewhat at odds with the assessments of other authors: "Public library use is not a right but a privilege regulated by law and the willingness of the board, administration, and library staff to make consistent use of those laws" (p. 74). As described earlier, the courts have determined that there is a Constitutional right to receive information. While libraries are permitted, under certain circumstances, to bar problem patrons, those circumstances must be grave enough to warrant depriving a patron of a civil right. Therefore, libraries must carefully develop an effective and legally defensible patron behavior policy.

Geiszler (1998) noted that each rule in a patron behavior policy must satisfy three conditions: it must be reasonable, cannot be overbroad, and cannot be vague. While many libraries have established patron behavior policies, often they do not meet these criteria and may be thinly-veiled attempts to single-out and bar the poor and homeless (Shen, 2002). For example, common among patron prohibitions is one against offensive body odors, despite the subjectivity of its enforcement, and its failing to prohibit such strong odors as perfumes. Many libraries prohibit bringing unusual or oversized objects into the library. Shen (2002) found that a public library in Tacomah, WA, had enacted a rule prohibiting bedrolls, large boxes, and bulky bags, and that libraries in Detroit, Savannah, and Charlotte also had rules restricting the size of objects that may be brought into the library. However, these rules may unfairly bar the homeless, who may need such things with them for survival (Shen, 2002).

For libraries attempting to draft a patron behavior policy, Holt \& Holt (2005) provide specific advice, including that the library should hire a lawyer with public agency experience, and write the document in simple language that staff and patrons can easily understand. They recommend soliciting input from library staff, and making sure staff members understand the final policy and how to implement it - as well as what their own rights are. Staff should be trained in how to appropriately document incidents, and administration must follow up on 
all incidence reports. If necessary, the library should hire private security personnel, and at all times maintain a good relationship with the local police.

Holt \& Holt (2005) offer guidance for handling an incident if one should arise, with maintaining safety the primary concern. The librarian should continually assess any potential for escalation to violence, avoid any physical contact with the patron, and respond to the patron calmly and pleasantly while directing others out of harm's way. Any intervention to address a problem behavior should be made incrementally. The librarian should begin by calmly advising the patron what specific behavior violates the policy. If the behavior continues, the librarian should ask the patron to leave. If the patron does not leave, the librarian should advise the patron that he or she is trespassing. If the patron still does not leave, the librarian should call the police. When the police arrive, if the patron is still there, the librarian should advise the police that the library wants to institute criminal charges. If the patron has left, the librarian should ask the police to file an official Offense Report. Throughout the incident, the librarian should remain keenly observant in order to accurately report all that transpired.

\section{Creating Change: Model Programs}

\section{“Get Into Reading” and “Book Well”: Literature as Therapy}

McLaine (2010, 2011) profiled two "bibliotherapy" programs used by public libraries with vulnerable populations like the homeless. In Get Into Reading (in the UK) and Book Well (in Australia) facilitators were trained to read literature aloud to groups of listeners, and elicit responses from them as a way of helping them talk about their thoughts and experiences. "It is hard to explain precisely what happens in a facilitated readaloud group. The new facilitators say 'something magic happens', and describe it as 'a slippery but powerful thing'. These groups go beyond a book club approach to literature, into therapeutic areas" (McLaine, 2010, p. 142).

Materials chosen had to have sufficient depth and complexity to evoke personal sharing of stories and experiences, and facilitators had to be trained in such skills as how to shift the focus of discussion from the text to the sharing of personal stories and experiences. This included selecting key stopping points within the text, facilitating issues that might arise, and allowing for silences while listeners absorbed and contemplated what they had heard (McLaine, 2010).

An evaluation of the Book Well program showed many positive outcomes. Attendance had remained high throughout the course of the program, as had participant enthusiasm. Benefits to participant wellbeing were also found, such as 
increased levels of confidence and social interaction, and reductions in anxiety (McLaine, 2011).

Programs like these accomplish a range of goals associated with public libraries. For example, they provide access to materials that the listeners might not have encountered on their own. By making connections between literature and listeners' personal experiences, they contribute to an appreciation for reading, education, and lifelong learning. And by fostering the development of underserved populations like the homeless, they contribute to the overall public good. Thus, programs like these may be useful interventions for public libraries to implement.

\section{San Francisco Public Library: Full-Time Social Worker on Staff}

In 2009, San Francisco Public Library became the first in the nation to add a fulltime social worker to its staff, to perform outreach to the library's large number of homeless patrons (Scott, 2012). With costs shared by Department of Public Health, this action came in response to increasing numbers of poor and homeless library patrons asking for help finding food and shelter, as well as a desire to make the library's main branch - located adjacent to one of San Francisco's poorest neighborhoods - a safer place (Robinson, 2010; Scott, 2012). The social worker oversees a cadre of "Health and Safety Associates" (some of whom were formerly homeless themselves) who keep an eye on patrons, approaching those who appear in need, and also making sure that all abide by the library's behavior policy (Guidelines for Library Use - see San Francisco Public Library, 2014). During its first three years of operation, the program provided outreach services to 1,200 homeless patrons (Scott, 2012).

As difficult economic times ground on, the demographics of homeless patrons widened to include students unable to make student loan payments, and families who had lost housing. Unlike a typical drop-in shelter, the library is a setting in which homeless patrons are not segregated away from the rest of society, and thus can receive assistance while still feeling part of the mainstream (Scott, 2012).

The program, in keeping with the social mission of public libraries and the American Library Association's core values, seeks to make the library accessible to all, as a necessary part of a democratic society (Scott, 2012). Serving as a national model, San Francisco Public Library's social work program has inspired other urban libraries to provide similar services, including public libraries in Sacramento and San Jose (Scott, 2012). 


\section{Martin Luther King, Jr. Library, San Jose: Community Connections}

The Martin Luther King, Jr., Library in San Jose is a unique institution with a combined city-university constituency and mission. Services for homeless patrons are comprised of an innovative network of library and community resources (Collins, Howard \& Miraflor, 2009).

A cornerstone of the library's approach is outreach. Rather than waiting for the homeless to come to the library, the library has devised ways to take its services, classes, and collections to other community agencies that serve the homeless. For example, librarians teach computer classes, family literacy programs, and lead story times and book discussion groups at social service agencies. Outreach efforts also serve to encourage the homeless to make subsequent visits to the library for programs, classes, and cultural events.

The library augmented its reference services by adding information resources specifically geared toward the needs of the homeless. "Social Workers in the Library" and "Lawyers in the Library" assist homeless patrons to negotiate a range of needs including shelter, employment, education, and childcare (Collins, Howard \& Miraflor, 2009; San Jose Public Library, 2014a; 2014b). The library also found it was possible to make adjustments to existing programs and services to make them more accessible to the homeless, such as scheduling programs around the times that shelters and soup kitchens operate, and offering temporary library cards that provide computer access (Collins, Howard \& Miraflor, 2009).

By partnering with community agencies, the King Library serves as a model for how to weave together a network of library and social services that provides maximum benefit without duplicating efforts or budgets.

\section{Trends in Librarian Education: Training Librarians to Meet Social Needs}

As difficult economic times impel public libraries to increase efforts to meet the informational and social service needs of poor and homeless patrons, so too are some library schools designing curricula to prepare future librarians for the social service aspects of their careers.

Dominican University's Graduate School of Library and Information Science and Graduate School of Social Work offer a dual degree program in Social Work (MSW) and Library and Information Science (MLIS). Emphasizing the intersection of librarianship with social work endeavors, the dual program draws upon the values, knowledge, and practices of both fields to better serve community needs. Graduates earn two distinct degrees - the MSW and MLIS - in a shorter time than would be required to earn the two degrees separately (Dominican University, 2014; Lai, 2013). 
At the time of its inception, the Dominican program was only the second of its kind in the nation, the other being the Master of Science in Information/Master of Social Work (MSI/MSW) program at the University of Michigan. Like the Dominican program, Michigan's MSI/MSW program combines the knowledge and skills of these two related fields so that future social workers will be better able to meet the informational needs of their clients, and future librarians will be better trained at furthering the public good (University of Michigan, 2014).

While not all library schools offer such dual degree programs, others may still address the social issues training of future librarians through such coursework as service learning experiences. For example, as a means of re-connecting library students with the social roots of librarianship, the SUNY Buffalo Department of Library and Information Studies created a service learning program in which library students designed and established a library for a homeless shelter (Peterson, 2003). Collaborating with shelter administrators, they tailored all aspects of the project, including collection building, writing a mission statement, and establishing a board of directors, to the particular needs of the homeless living in the shelter.

\section{Discussion}

With a fundamental social role to improve the public good, public libraries (and librarians) face both opportunities and challenges in serving what is perhaps their most marginalized constituency - the homeless. This section distills some of the key recommendations for action from the material covered earlier in this paper. There are a number of things that librarians (or library students) can do as individuals, as well as actions that can be taken by libraries at the institutional level.

\section{Things a Librarian (or Library Student) Can Do}

- Examine one's own attitudes for hidden classism and prejudices that may blame the poor for their predicament. Harboring prejudices or classist ideologies, even unconsciously, can surface in decisions and actions that make the poor and homeless feel unworthy or disparaged (Berman, 2007; Holt, 2006).

- Seek out related coursework and social service experiences while in school or through continuing education (Lai, 2012; Zetterwall, 2014). The American Library Association recognizes the need for training programs to prepare library staff to deliver services to constituents who are poor or homeless (American Library Association, 2014). 
- Understand that the homeless are a diverse group with basic and higher-level needs. Like all human beings, the homeless need not only food and shelter, but opportunities for mental and spiritual development, and for fostering positive interpersonal relationships. They are not a homogeneous group, but include a range of ages, family statuses, and representatives of both genders, and the causes and duration of their homelessness vary widely (Hersberger, 2005; Holt \& Holt, 2010; Muggleton \& Ruthven, 2011).

- Explore and make contact with community resources for the homeless. There is a growing convergence between librarianship and social services (Dominican University, 2014; Lai, 2012; Zetterwall, 2014). By searching the Internet, probing local news and media sources, and making personal connections, librarians can become their own experts on the subject, as well as contribute to library efforts to expand services.

\section{Things a Library Can Do}

- Develop an effective and legally defensible patron behavior policy. In order to maintain the safety and order of the library, and keep it a pleasant place for all, every library needs to develop such a policy, under the guidance of an experienced attorney (Holt \& Holt, 2005).

- Include a homeless resource page on the library's website. With this information easily accessible on the library's website, librarians and patrons alike will be able to find the needed resources efficiently (Holt \& Holt 2010).

- Partner with community organizations who work with the homeless. With budgets tight during difficult economic times, forming collaborations allows both the library and its partner organizations to further their missions with shared resources (American Library Association, 2014; Collins, Howard \& Miraflor, 2009).

- Make experts like social workers and lawyers available in the library, either as regular staff or visiting professionals. Reference librarians may not always have the necessary expertise to answer legal questions or navigate the local social service system. Public libraries like those in San Francisco and San Jose have found it very effective to locate individuals with that kind of expertise right in the library - either full time, or on a part-time visiting basis (Collins, Howard \& Miraflor, 2009; Scott, 2012).

\section{Conclusion}

Is it possible to move beyond seeing the homeless as a separate constituency, while still recognizing their unique needs? Must librarians always be "caught in the middle" as referees between "regular" patrons and homeless patrons, serving 
as a kind of benevolent police force? Can libraries create a truly "classless society" among their patrons? Perhaps only in a utopian world can there be such blurring of status boundaries. Yet, public libraries are unique in the way they bring members of all social strata together under one roof, each pursuing some activity relating to an aspect of self-care, self-nurturance, or inner development. Public libraries, then, may not only be institutional outgrowths of a democratic society, they may also be its incubators, as people learn to share space with, and interact with, people who may be from very different stations in society than their own. By fully responding to the American Library Association's core values of equal access for all, public libraries model the behavior they would have their patrons emulate, not only demonstrating but creating the kind of society for which they stand. 


\section{References}

American Library Association. (2004). Core values of librarianship. Retrieved from http://www.ala.org/advocacy/intfreedom/statementspols/corevalues

American Library Association. (2008). Library services for the poor. Handbook of Organization 2008-2009. Chicago: ALA.

American Library Association. (2012). Hunger, homelessness, and poverty task force (HHPTF). Retrieved from http://www.ala.org/srrt/hungerhomelessness-and-poverty-task-force-hhptf

American Library Association. (2014). Library services to the poor. Retrieved from http://www.ala.org/aboutala/governance/policymanual /updatedpolicymanual/section2/52libsvcsandrespon\#B.8.10

Ayers, S. (2006). The poor and homeless: An opportunity for libraries to serve. Southeastern Librarian, 54, 66-74.

Ballard-Thrower, R. A. (1992). Kreimer v. Morristown / Analysis of library policies and constitutional issues. George Library Quarterly, 29, 9-11.

Barber, G. (2012). The legacy: Kreimer v. Bureau of Police, twenty years later. Library \& Archival Security, 25, 89-94. doi:10.1080/01960075.2012.657948

Berman, S. (2007) Classism in the stacks: Libraries and poverty. Journal of Information Ethics, 16, 103-110.

Collins, L. N., Howard, F., \& Miraflor, A. (2009). Addressing the needs of the homeless: A San Jose library partnership approach. Reference Librarian, 50, 109-116. doi:10.1080/02763870802546472

Dominican University. (2014). Master of social work/Master of library and information science. Retrieved from http://socialwork.dom.edu/academics/msw-mlis

Geiszler, R. W. (1998). Patron behavior policies in the public library: Kreimer v. Morristown revisited. Journal of Information Ethics, 7, 54-67. 
Hersberger, J. (2002/2003). Are the economically poor information poor? Does the digital divide affect the homeless and access to information? Canadian Journal of Information \& Library Sciences, 27(3), 45-63.

Hersberger, J. (2005). The homeless and information needs and services. Reference \& User Services Quarterly, 44(3), 199-202.

Hitchcock, L. A. (2005). Do you really want to be a forum? Library Philosophy and Practice, 8, 1-11.

Holt, L. E., \& Holt, G. (2010). Public library services for the poor: Doing all we can. Chicago: ALA.

Holt, G. E., \& Holt, L. E. (2005). Setting and applying appropriate rules governing patron behavior. Public Library Quarterly, 24, 73-85. doi:10.1300/J118v24n01_09

Holt, G. E. (2006). Fitting library services into the lives of the poor. The Bottom Line: Managing Library Finances, 19(4), 179-186. doi:10.1108/08880450610713063

Jaeger, P. T., Bertot, J. C., \& Thompson, K. M. (2012). The intersection of public policy and public access: Digital divides, digital literacy, digital inclusion, and public libraries. Public Library Quarterly, 31, 1-20. doi:10.1080/01616846.2012.654728

Lai, P. (2012, August 8). Libraries and public service [Web log post]. Retrieved from http://hacklibraryschool.com/2012/08/08/libraries-and-publicservice/

Lai, P. (2013, August 4). Dominican University's joint MLIS/MSW program. Retrieved from http://mlismsw.wordpress.com/2013/08/04/dominicanuniversitys-joint-mlismsw-program/

MacNaughton, W. (2011, May 13). Meanwhile, the San Francisco Public Library [Web log post]. Retrieved from http://therumpus.net/2011/05/meanwhilethe-san-francisco-public-library/

Manley, M. (1998). Best of times; Worst of times. American Libraries, May, 128. 
McCook, K., \& Phenix, K. J. (2006). Public libraries and human rights. Public Library Quarterly, 25, 57-73. doi:10.1300/J118v25n01_05

McLaine, S. (2010). Healing for the soul: The Book Well program. Australasian Public Libraries And Information Services, 23(4), 141-147.

McLaine, S. (2011). The Victorian Book Well program. Aplis, 24(2), 82-84.

Muggleton, T. H. \& Ruthven, I. (2011). Homelessness and access to the informational mainstream. Journal of Documentation, 68, 218-237. doi:10.1108/00220411211209203

Murphy, J. (1999). When the rights of the many outweigh the rights of the few: The "legitimate" versus the homeless patron in the public library. Current Studies in Librarianship, 23(1/2), 50-60.

Norfolk, S. D. (1995). Project Horizons: A closer look. Journal of Youth Services in Libraries, 8, 273-278.

Peterson, L. (2003). Using a homeless shelter as a library education learning laboratory: Incorporating service-learning in a graduate-level information sources and services in the social sciences course. Reference \& User Services Quarterly, 52, 307-310.

Robinson, C. W. (2010). A Real social worker! Library Administrator's Digest, $45(6), 45$.

San Francisco Public Library. (2014). Guidelines for library use. Retrieved from http://sfpl.org/index.php?pg=2000004201

San Jose Public Library. (2014a). Lawyers in the library. Retrieved from http://www.sjpl.org/event/lawyers-library

San Jose Public Library. (2014b). Social Workers in the Library. Retrieved from http://www.sjpl.org/event/social-workers-library

Scott, J. (2012, January 18). Helping the homeless at the S.F. Public Library [Web log post]. Retrieved from http://kalw.org/post/helping-homeless-sf-publiclibrary 
Shen, L. (2002). The dilemma of urban library service for the homeless. Current Studies In Librarianship, 26, 77-83.

Torrey, E. F., Esposito, R., \& Geller, J. (2009). Problems associated with mentally ill individuals in public libraries. Public Libraries, 48(3), 45-51.

University of Michigan. (2014). Dual degrees. Retrieved from https://www.si.umich.edu/programs/msi/dual-degrees

Zetterwall, S. (2014, March 1). What is "whole person librarianship"? [Web log post]. Retrieved from http://mlismsw.wordpress.com/2014/03/01/what-iswhole-person-librarianship/ 